Editorial

\title{
Introduction to "International Broadcasting and Public Diplomacy in the 21st Century"
}

\author{
Gary D. Rawnsley \\ Department of International Politics, Aberystwyth University, Aberystwyth, SY23 3FL, UK; E-Mail: gdr1@aber.ac.uk
}

Submitted: 8 April 2016 | Published: 4 May 2016

\begin{abstract}
International broadcasting remains a key activity in public diplomacy. In this Introduction I discuss how international broadcasting has long been associated with the projection of foreign policy interests, from an instrument of empire building in the 1920s and 1930s, through the Cold War and beyond. In particular, the Introduction evaluates how modern Information Communications Technologies, especially the internet and social media, have transformed the way international broadcasting contributes to public diplomacy.
\end{abstract}

\section{Keywords}

broadcasting; Internet; propaganda; public diplomacy; soft power

\section{Issue}

This editorial is part of the issue "International Broadcasting and Public Diplomacy in the 21st Century", edited by Gary D. Rawnsley (Aberystwyth University, UK).

(C) 2016 by the author; licensee Cogitatio (Lisbon, Portugal). This article is licensed under a Creative Commons Attribution 4.0 International License (CC BY).

\section{Introduction}

Across the world governments have embraced with enthusiasm the idea that they must exercise 'soft power' ever since Professor Joseph Nye first introduced the term at the beginning of the 1990s. Few-within both political circles and the academic community-appear to understand what soft power really means, with many preferring to emphasise the attraction of cultural products rather than a particular society's positive values and behaviour. One only needs to refer to the annual Monocle soft power survey to see how the concept is misconstrued and therefore misused. Soft power, if it exists at all (and I have reason to doubt that it does), 'depends on others' knowledge of one's alluring qualities' and 'on knowing exactly how to make their ideas and themselves attractive to a target population' (Mattern, 2005, pp. 584-588). Communicating 'one's alluring qualities', values and positive behaviour to the international community is the responsibility of public diplomacy, a term first attributed in most literature on the subject to Edmund Gullion, Dean of the Fletcher School of Law and Diplomacy at Tufts Universi- ty. ${ }^{1}$ Public diplomacy refers to 'the process by which direct relations with people in another country are pursued' by state and non-state actors 'to advance the interests and extend the values of those being represented' (Sharp, 2007, p. 6). Jowett and O'Donnell's definition is broader. Public diplomacy, they write:

\begin{abstract}
"deals with the influence of public attitudes on the formation and execution of foreign policies. It encompasses dimensions of international relations beyond traditional diplomacy; the cultivation of governments of public opinion in other countries; the interaction of private groups and interests in one country with another; the reporting of foreign affairs and its impact on policy; communications between those whose job is communication, as diplomats and foreign correspondents; and the process of intercultural communications" (Jowett \& O’Donnell, 2012, p. 287).
\end{abstract}

\footnotetext{
${ }^{1}$ Nicholas Cull's research (2009, p. 19) has revealed that the earliest use of the term 'public diplomacy' was in the London Times, in 1856.
} 
Nicholas Cull (2008) developed a taxonomy that proposed defining public diplomacy by five fields of activity: listening, advocacy, cultural diplomacy, exchange diplomacy and international broadcasting. The papers gathered together in this special issue demonstrate that international broadcasting, described by Monroe Price $(2003$, p. 53) as an 'elegant term for...the use of electronic media by one society to shape the opinion of the people and leaders of another', is a mechanism of public diplomacy that remains as relevant today as ever. However, they also encourage a wider understanding of international broadcasting and its relationship with public diplomacy. While research in the field has been dominated by analyses of 'traditional' or 'mainstream' media, such as radio and television, now we must also consider more carefully the impact of the Internet, social media and other platforms of communication on how a political or diplomatic actor uses international broadcasting to further their own interests and ambitions.

International broadcasting enjoys a long history. The earliest recorded instance of the organised use of radio for political purposes was in 1926 when Russia used radio broadcasting to demand the return of Bessarabia from Romania. Moscow was also the first to employ international radio as a tool of its foreign policy: the inauguration of Radio Moscow in 1929, first in four languages and growing to 11 by 1933, resulted from an aspiration to explain the Communist revolution to the wider world and communicate its accomplishments. Its broadcasts found an audience. In 1930, Hugh Dalton at the British Foreign Office received a letter expressing concern that Moscow radio had been heard broadcasting in English and 'urging revolution repeatedly' (West, 1987, p. 22). ${ }^{2}$ Holland followed with its Empire Service in 1927, China in 1928 (first as the Central Broadcasting System and then as Radio China International in 1941), Germany in 1929, France in 1931, the BBC's own Empire Service in 1932, and Japan in 1934. The Voice of America started to broadcast in 1942, making the US a relatively junior member of the club (Browne, 1982; Mansell, 1982; Partner, 1988; Pirsein, 1979; Walker, 1992).

Radio continued to dominate international propaganda and public diplomacy during the Second World War and through the Cold War; and alongside the continued development of the BBC Overseas Services, Voice of America, Radio Moscow, Deutsche Welle, etc., so-called 'surrogate' radio stations (such as Radios Free Europe, Liberty and Asia and Radio and TV Marti) were launched to take the propaganda war direct to

\footnotetext{
2 This brought for the first time the act of listening and international broadcasting together as per Cull's (2008) typology: the letter sent to Dalton provoked the British government into organising the first systematic monitoring of international radio broadcasts by the Post Office, a task later taken over by the BBC.
}

Communist audiences in their own languages (Cull, 2008; Nelson, 1997; Price, 2003; Rawnsley, 1996, 1999, 2013).

On 17 January 1991, a coalition of 34 nations led by the US launched combat operations to expel Iraq from Kuwait. As Operation Desert Storm began, television audiences around the world found on their national TV news networks 'live' coverage from a new kid on the block, CNN...only they did not see much at all. In fact, the opening hours of the war were in sound only as the three CNN reporters described from the safety of their hotel room the bombs falling on Baghdad, while audiences saw only their photos superimposed on maps of Baghdad and Iraq. The first conflict not only of the New World Order, but also of the 'new' media age, characterised by $24 / 7$ electronic news-gathering and live satellite broadcasting, was reported as if on radio (Taylor, 1992). Yet the Gulf War marked the arrival of CNN as a serious major player on the emerging international television news landscape, and others would be quick to follow their approach to broadcasting.

The rapid development of live round-the-clock international news programming has since morphed again to provide for live and instant news broadcasting via the Internet. New communications technologies have shattered forever the spatial and temporal boundaries that constrained their predecessors and now allow the 'deterritorialization' of news broadcasting. Moreover, the likes of CNN and the BBC no longer tower above the global news media environment that is now characterised by more regional actors facilitating a multi-directional flow of news and information: Al-Jazeera, NHK, RT, CCTV, India's NDTV, the panAfrican Channel S24, and Singapore's Channel News Asia all provide alternative voices and perspectives on global issues, while inviting us to gaze upon local and regional news that would otherwise be ignored by the dominant networks.

The speed at which news, information and other forms of communications now travel across the globe has transformed diplomatic practice (Gilboa, 2008; Seib, 2012). While television and even radio remain the primary method of communication in many parts of the world (see the paper by Jacob in this collection) the social media and the Internet have expanded the room (though some may prefer to call it an echo chamber) in which conversations take place. This has two important consequences. First, all members of a diplomatic mission are encouraged to be more sensitive than at any time in the past to the possible impact on public opinion of what they do and say. Mark Twain is credited with saying, 'A lie can travel half way around the world while the truth is putting on its boots'. One can only speculate what Twain would have thought about the power of Twitter and other social media to make events real just because they are discussed in cyberspace. 
The second consequence of what has been called the 'new media' age is that the number and type of actors involved in public diplomacy has grown. We can no longer maintain our focus on states, governments, foreign ministers and press officers. Rather, a more accurate picture of public diplomacy today requires a broader perspective that includes the activities of groups and individuals operating outside the confines of states and governments and who can deploy (and sometimes innovate) methods of international broadcasting for their own strategic ambitions.

As I write in the Spring of 2016, one such group is dominating news headlines across the world: Islamic State (also called ISIS, ISIL and Daesh) is not only carving out territory for itself in the Middle East, but is also responsible for terrorist activities in Europe. Their development and use of new communication platforms, documented in a series of volumes (for example, see Stern \& Berger, 2015; and Atwan, 2015), presents new challenges for international relations which require a more nuanced and creative response from governments and diplomats operating in a modern media ecology which is undergoing almost constant reinvention.

This collection of papers offers a broad understanding of this new media ecology and its interaction with public diplomacy. The authors demonstrate the innovative practices that international actors, whether they are governments or terrorists, use to project and communicate their power, interests and ambitions. Yet for all the changes that have occurred in the global media landscape, international broadcasters and public diplomats working in the new media age still face challenges that their predecessors would recognise. After all, the history of international broadcasting since the 1920s is one of actors playing 'catch-up' as technological development gallops ahead and new geopolitical problems demand new communication responses (Rawnsley, 2012).

\section{Acknowledgments}

In addition to thanking all colleagues who submitted papers for this special issue and responded in such a timely fashion to the feedback of the reviewers, I also acknowledge the hard work undertaken by all those who offered comments on the papers. Finally, I should also thank the team at Media and Communication, especially António Vieira, for inviting me to edit this special issue, and for all their hard work and above all patience in assembling this collection.

\section{Conflict of Interests}

The author declares no conflict of interests.

\section{References}

Atwan, A. B. (2015). Islamic State: The digital caliphate.
London: Saqi Books.

Browne, D. R. (1982). International radio broadcasting: The limits of the limitless medium. New York: Praeger.

Cull, N. (2008). The Cold War and the United States Information Agency: American propaganda and public diplomacy, 1945-1989. Cambridge: Cambridge University Press.

Cull, N. J. (2009). Public diplomacy before Gullion: The evolution of a phrase. In N. Snow \& P. M. Taylor (Eds.), The Routledge handbook of public diplomacy (pp. 19-23. London: Routledge.

Gilboa, E. (2008). Searching for a theory of public diplomacy. Annals of the American Academy of Political and Social Science, 616, 55-77.

Jowett, G. S., \& O'Donnell, V. (2012). Propaganda and persuasion (5th ed.). Thousand Oaks, CA: Sage.

Mansell, G. (1982). Let truth be told: 50 years of BBC external broadcasting. London: BBC.

Mattern, J. B. (2005). 'Why "soft power" isn't so soft: Representational force and the sociolinguistic construction of attraction in world politics. MillenniumJournal of International Studies, 33(3), 583-612.

Nelson, M. (1997). War in the black heavens: The battles of Western broadcasting in the Cold War. New York: Syracuse University Press.

Partner, P. (1988). Arab voices: The BBC Arabic service, 1938-1988. London: BBC.

Pirsein, R. W. (1979). The voice of America: An history of international broadcasting activities of the United States government, 1940-1962. New York: Arno Press.

Price, M. (2003). Public diplomacy and the transformation of international broadcasting. Cardoza Arts and Entertainment Law Journal, 21(1), 51-85.

Rawnsley, G. D. (1996). Radio diplomacy and propaganda: The BBC and VoA in international politics, 195664. London: Macmillan.

Rawnsley, G. D. (Ed.). (1999). Cold War propaganda in the 1950s. London: Macmillan.

Rawnsley, G. D. (2012). The media and the information environment, ten years after 9/11. In R. Utley (Ed.), Perspectives on 9/11. London: Ashgate.

Rawnsley, G. D. (2013). Radio free Asia and China's harmonious society. In D. Welch (Ed.), Propaganda, power and persuasion: From World War I to Wikileaks. London: I.B. Taurus.

Seib, P. (2012). Real-time diplomacy: Politics and power in the social media era. New York: Palgrave Macmillan

Sharp, P. (2007). Revolutionary states, outlaw regimes and the techniques of public diplomacy. In J. Melissen (Ed.), The new public diplomacy (pp. 106-123). London: Palgrave.

Stern, J., \& Berger, J. M. (2015). ISIS: The state of terror. London: William Collins.

Taylor, P. M. (1992). War and the media: Propaganda 
and persuasion in the Gulf War. Manchester: Manchester University Press.

Walker, A. (1992). A skyful of freedom: 60 years of the
$B B C$ world service. London: Broadside.

West, W. J. (1987). Truth betrayed. London: Duckworth.

\section{About the Author}

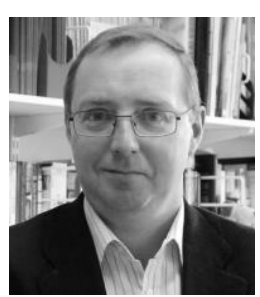

\section{Professor Gary D. Rawnsley}

Gary D. Rawnsley is Professor of Public Diplomacy in the Department of International Politics, Aberystwyth University. He is the co-editor (with Naren Chitty, Li Ji and Craig Hayden) of the forthcoming Routledge Handbook of Soft Power. 